Електронне наукове фахове видання "Ефективна економіка" включено до переліку наукових фахових видань України з питань економіки (Наказ Міністерства освіти і науки України від 11.07.2019 № 975) www. economy.nayka.com. ua | № 12, 2019|27.12.2019 p.

DOI: $\underline{10.32702 / 2307-2105-2019.12 .95}$

удК 338

T. G. Tolpezhnikova

Candidate of Economic Sciences,

Associate Professor of the Department of Management of Foreign Economic and Innovation Activities,

Donetsk State University of Management, Mariupol

ORCID: 0000-0001-7404-5912

\title{
THE INFLUENCE OF INTERCULTURAL FACTORS ON THE EFFECTIVENESS OF FOREIGN ECONOMIC ACTIVITY OF THE ENTERPRISE
}

\author{
Т. Г. Толпежнікова,
}

к. е. н., доцент кафедри менеджменту зовнішньоекономічної та інноваційної діяльності, Донецький державний університет управління, м. Маріуполь

\section{ВПЛИВ МІЖКУЛЬТУРНИХ ФАКТОРІВ НА ЕФЕКТИВНІСТЬ ЗОВНІШНЬОЕКОНОМІЧНОЇ ДІЯЛЬНОСТІ ПІДПРИЄМСТВА}

The article considers the influence of globalization on foreign economic activity, international relations and competition, examines the essence of cross-cultural management as a factor of competitiveness for effective foreign economic activity of the enterprise in modern conditions, examines the positive experience of introducing cross-cultural management in the activities of international companies. The position of Ukraine in the cultural environment is analyzed in accordance with model of Gerd Hofsted. Modern conditions of functioning of enterprises engaged in foreign economic activity require the knowledge and understanding of each other by the participants of this process. Cultural differences in economic activity can be both positive and negative influences. Globalization at the present stage contributes to the formation of the effective intercultural dialogue in the implementation of foreign economic activities. Cross-cultural management is an integral part of the human resources management system, which provides the development of training technologies for effective business management in a variety of cultures in order to prevent cross-cultural conflicts. The more diverse the cultural field of foreign economic activity, the higher the reputational risks, the more cross-cultural differences are manifested, the higher communicative barriers and critical requirements for the manager's cross-cultural competence are formed. Therefore, when developing corporate strategies of enterprises engaged in foreign economic activity, it is necessary to take into account cross-cultural factors. It is important for the manager to take into account different aspects of management practice in different countries. The current state of implementation of cross-cultural management is rather weak. It is necessary to study and implement international cross-cultural management to strengthen them. For the effective implementation of cross-cultural management in the practice of Ukrainian enterprises it is necessary: to comprehensively study the cultural diversity of nations; to create and maintain an atmosphere of respect for another culture; to take full advantage of international partnership; to research their specifics on consumer demand before entering foreign markets. 
В статті розглянуто вплив глобалізації на зовнішньоекономічну діяльність, міжнародні відносини та конкуренцію, розглянуто сутність крос-культурного менеджменту як чинника конкурентоспроможності для ефективного зовнішньоекономічної діяльності підприємства в сучасних умовах, досліджений позитивний досвід впровадження крос-культурного менеджменту в діяльності міжнародних компаній. Проаналізована позиція України в культурному середовищі відповідно до моделі Гірда Хофстеда. Сучасні умови функиіонування підприємств, щзо займаються зовнішньоекономічною діяльністю вимагають знань та розуміння один одного учасниками цього процесу. Культурні відмінності ведення господарської діяльності можуть бути як позитивним, так і негативних фактором впливу. Глобалізачія на сучасному етапі сприяе формуванню ефективного міжкультурного діалогу при здійсненні зовнішньоекономічної діяльності. Відмінність культур різних країн світу проявлясться в будь-якому національному феномені, включаючи $i$ менеджмент. Чим різноманітніше культурне поле ведення зовнішньоекономічної діяльності, тим вищі репутаційні ризики, гостріше виявляються крос-культурні відмінності, формуються вищі комунікативні бар'єри та критичніші вимоги до крос-культурної компетениії менеджера. Тому при розробці корпоративних стратегій підприємств, які займаються зовнішньоекономічною діяльність необхідно враховувати крос-культурні фактори. Менеджеру важливо врахувати різноманітні аспекти управлінської практики в різних краӥнах. Сучасний стан впровадження крос-культурного менеджменту має досить слабкі позиції. Для їх посилення необхідно вивчення та впровадження міжнародного кроскультурного менеджменту. Для ефективного впровадження крос- культурного менеджменту в практику українських підприємств слід: всебічно вивчати культурне різноманіття начій; створювати $і$ підтримувати атмосферу поваги по віднотенню до іншої культури; використовувати всі переваги міжнародного партнерства; перед тим, як входити на іноземні ринки, досліджувати їх специфіку щзодо споживчого попиту.

Key words: foreign economic activity; intercultural communications; cross-cultural management; efficiency of activity.

Ключові слова: зовнішньоекономічна діяльність; міжкультурні комунікації; кроскультурний менеджмент; ефективність діяльності.

Problem statement. National business culture significantly affects various aspects of the organization's life approaches to leadership and attitude to the authorities, style of negotiating, perception and enforcement of laws, planning, forms and methods of monitoring, personal and group relationships of people, etc. The large number of national business cultures existing in different countries, the growing openness of markets, globalization trends in the global economy necessitate the study and consideration in practice of the cross-specifics of doing business.

Knowledge of value systems, behavioral models and stereotypes, understanding of national and international characteristics of human behavior in different countries significantly increase management efficiency, make it possible to achieve mutual understanding during business meetings and negotiations, resolve conflict situations and prevent the emergence of new ones. That is why the management of the company, which takes place on the border of two or more different cultures, causes considerable interest among scientists and practitioners and stands out today in a separate branch of international management - cross-cultural management.

Analysis of recent research and publications. Special attention was paid to the issues of intercultural management and its role in the everyday activities of enterprise such authors as R. Lewis, T. Parsons, M. Rokich, M. Tayeb, A. Tropenrans, Yu. Petrushenko, T. Karmanova and A. Efimov [1-9].

The aim of the article. To considerate the cross-cultural management as a factor of influence to the effectiveness of the foreign economic activity of the enterprise.

Presentation of the main research material. Globalization requires society to have great knowledge and understanding of each other. Cultural differences between nations became a business subject not so long ago, in the early 70s. For the first time, small countries showed interest in intercultural issues: first of all, Finland, Sweden, Denmark and the Netherlands. They wanted to show their face to the world, so that they would know better. Later, countries such as Germany and Britain joined them. Then America, Italy, Spain, France and other countries.

Cultural problems cannot be investigated without regard to the philosophical problem of values. Noteworthy is the moral position according to which a business that ignores the principles of humanism and patriotism is immoral, ineffective. Business culture offers the norms and values of labor interaction, and also includes "specific forms and 
methods of people's interaction in solving business issues", which include strategies and tactics for achieving production goals, methods of persuasion and influence [5].

Each person involuntarily projects his speech stereotypes and speech behavior on those with whom he has to communicate, regardless of their cultural, social, ethnic, religious or any other difference. Often this is due to the fact that universal human norms and values are, as it were, exaggerated, while national, social and unique ones are underestimated. This is especially pronounced in language communication, in which the linguistic and cultural barrier can be not only an obstacle in the process of communication, but also lead to the so-called "communicative failures". Morality and ethics form the basis of a business culture, which is understood as accepted by the leadership of the organization and supported by staff spiritual values. And although many people think that business culture concerns only the internal life of the team, in fact, it forms the external life of the organization (external relations). The business culture of the organization is manifested in the behavior of employees, in their perception of themselves, the organization as a whole and the environment. The central place in organizational culture is occupied by basic values, i.e. officially adopted by the organization, the set of the most significant and unchanging principles on which employee behavior is based [4].

The success of foreign economic activity depends on knowledge and ability to use the technique of business communication. Business communication is primarily communication, exchange of information relevant to the participants in the communication. Communicative activity is a complex multi-channel system of human interaction

There are four communication functions; combining, they give the communication processes a specific specificity in specific forms:

- Sign (semantic) function - is a means of human communication, for example, the folk and literary languages are the most important means of mastering the national culture.

- Value (axiological) function - reflects the quality state of culture, forms a person's needs and orientations, by which one can judge the level of culture of a person and society.

- The normative function, organizing and life-meaning function of cultural norms, their varieties and symbols. Norms, taboos, norms, principles, norms of value.

- The translational function is the transfer of human experience, historical continuity, the transfer of social experience and cultural traditions [5].

Communication style is an individual-typological features of the interaction between people. The foundation of the personality communication style is its moral and ethical attitudes and assessments of the socio-ethical attitudes of society. All means of communication are divided into two large groups: verbal and nonverbal. Thus, the technology of culture of business communication can be interpreted as a set of moral principles and norms governing the process of interconnection and interaction of people in the areas of work. The need for moral regulation of communication in the field of labor determines the need for streamlining business life. Satisfying this need, culture plays an important communication role in the communication of people.

Culture is a multidimensional concept. Culture - a combination of material and spiritual values, life ideas, behavior patterns, norms, methods and techniques of human activity:

- reflecting a certain level of historical development of society and human;

- embodied in subject, material media;

- transmitted to future generations [6].

In a broader sense, culture is the collective programming of the thinking of a group of people, which affects the behavior of a person and the community to which he belongs. Culture is a product of millions of minds, filtered by hundreds of generations and presented in the form of sustainable values, beliefs and communication models. Knowing the features of this programming, you can build a communication model that will allow you to successfully communicate with representatives of other cultures. In relation to our subsequent reasoning, culture is a system of values, norms, and knowledge that has developed in a social community and regulates its vital functions [10].

The difference in cultures of different countries of the world is manifested in any national phenomenon, including management. The more diverse is the cultural field of conducting foreign economic activity, the higher are reputation risks, the more are cross-cultural differences, the higher communicative barriers and critical requirements for the manager's cross-cultural competence are formed. Therefore, when developing corporate strategies for enterprises engaged in innovative business, cross-cultural factors must be taken into account. Therefore, it is important for the manager to take into account various aspects of managerial practice in different countries. Building interpersonal relational son in a multicultural team or managing organizations located in different countries of the world, interaction with foreign partners is always a clash of different national cultures. Often in business relations between representatives of different countries, misunderstandings arise. Therefore, "cross-cultural" knowledge is needed by modern managers to avoid such a problem [1].

Today, the management of foreign economic activity have to take into account national models, the similarities and differences of which are determined by the cultural and historical conditions of the various countries and regions. According to experts, cross-cultural knowledge is needed for modern managers for many tasks - they not only manage multinational and multicultural personnel, but also develop business in new countries, negotiate and the like. in fact, in international negotiations, knowledge of the mentality of the opposite side is the key to success [6].

The concept of "culture" is understood as a variety of common knowledge, behavior, values, beliefs, preferences, basic meanings and assumptions, various functions of each people [9]. The culture, predominantly national, with cultural differences, is not perceived by workers as a serious complication. In fact, the ways in which 
cultural differences are reflected differ. Therefore, companies develop systems and structures that allow them to overcome intercultural barriers and consider cross-cultural interaction as a source of learning for the company [6]. Thus, the manager's status in Germany is determined by his achievements, duration of service, qualifications, in France and England - by origin, elite education, intellectualism and grace, in the USA - by talent, initiative, ability to achieve goals, in China, Japan - by education, morality, paternalistic attitude to subordinates, in Ukraine - firmness in upholding one's position, tolerance to another point of view, tact, endurance, sense of humor [4]. That is, we can say that this is implicit subconscious knowledge. Communication is a two-way process that requires communication skills from partners and, last but not least, the ability to listen to each other. Different cultures not only use speech differently, but also listen differently. There are good listeners (Germans, Swedes) and there are bad ones (French, Spaniards). Others, such as Americans, listen carefully or indifferently depending on the nature of the speech [7]. And it is logical that they are different for each people.

In order to determine the place and specificity of the existence of Ukrainian business structures in the overall system of Ukrainian economic relations, it is necessary to carry out a comparative analysis of national culture and cultures and cultures of other countries. For this purpose, it is advisable to use the model of the Dutch scientist Gerd Hofsted. Its model is based on the following value measures: PDI (power distance), UAI - uncertainty avoidance, IND - individualism/collectivism, MAS - masculine/feminine, LTO - Confucian dynamism [7].

Table 1.

Distance indicators of Ukraine and other countries [9]

\begin{tabular}{|l|l|l|l|l|l|l|}
\hline Country & PDI & UAI & IND & MAS & LTO & DC \\
\hline Ukraine & 78 & 93 & 30 & 54 & 40 & \\
\hline Romania & 90 & 90 & 30 & 42 & & 4.31 \\
\hline Bulgaria & 70 & 85 & 30 & 40 & & 4.50 \\
\hline Turkey & 66 & 85 & 37 & 45 & & 4.60 \\
\hline Mexico & 81 & 82 & 30 & 69 & & 4.71 \\
\hline Russia & 93 & 95 & 39 & 36 & & 6.29 \\
\hline \multicolumn{1}{|c|}{$\ldots$} & $\ldots$ & $\ldots$ & $\ldots$ & $\ldots$ & $\ldots$ \\
\hline United Kingdom & 35 & 35 & 89 & 66 & 25 & 19,04 \\
\hline Austria & 11 & 70 & 55 & 79 & & 19,79 \\
\hline Sweden & 31 & 29 & 71 & 5 & 33 & 20,43 \\
\hline Jamaica & 45 & 13 & 39 & 68 & & 22,03 \\
\hline Denmark & 18 & 23 & 74 & 16 & & 27,25 \\
\hline
\end{tabular}

According to the table 1, cultures of countries such as Romania, Bulgaria, Turkey, Mexico are close to Ukraine, and the UK, Austria, Sweden, Jamaica, and Denmark are most different from our culture. Cross-cultural management is underdeveloped in Ukraine. Therefore, it is necessary to help strengthen the integration of Ukraine into intercultural relations with other countries in order to increase the effectiveness of foreign economic activity.

According to the positive experience of international enterprises of foreign economic activity, it is advisable to formulate the main rules for conducting foreign economic activity in order to open up new opportunities for Ukrainian enterprises in the foreign market. The use of the main ways of improving cross-cultural management in Ukraine will lead to successful conduct of foreign economic activity, which will be the impetus for the construction of a new market economy. Such theoretical recommendations may be reflected in the specific practical actions of the heads of enterprises aimed at carrying out foreign economic activities [5].

For the effective implementation of cross-cultural management in the practice of Ukrainian enterprises should:

1) comprehensive study of the cultural diversity of nations;

2) create and maintain an atmosphere of respect for another culture;

3) take full advantage of the international partnership;

4) before entering foreign markets, research their specifics on consumer demand.

Conclusions. The foreign economic activity in modern conditions requires business owners and managers to take a serious approach not only to quality and international standards, but also with the specifics of adapting to new business conditions. Such specific features include the ability to integrate national products into different national and cultural differences. Such socio-cultural aspect is caused by a wide variety of business environments, and they are sharply manifested in the cultural differences of different nationalities. It is in such conditions that the introduction of cross-cultural management becomes more relevant to better understand the customs, traditions and mentality of the country with which the joint activity is planned. Studying the world experience of cross-cultural management will allow to work more successfully in a multinational environment, and borrowing the main ways of implementation will lead to long-term, competitive relations in the world market.

\section{References.}

1. Hodvinh, Vonh. (2009), "Three keys to successful cross-cultural management", [Online], available at: http://www.mim.kiev.ua/press/news/2009/1593/ (Accessed 5 December 2019). 
2. Yefimova, A.H. (2012), "Development of cross-cultural management at Ukrainian enterprises", Upravlinnia rozvytkom, vol. 6, pp. 44-45.

3. The Verkhovna Rada of Ukraine (2019), The Law of Ukraine "On foreign economic activity", available at: https://zakon.rada.gov.ua/laws/show/959-12 (Accessed 9 December 2019).

4. Kalyberda, L.P. (2006), "Cross-cultural management and the formation of cultural competence of students", Visnyk Kyivs'koho instytutu biznesu ta tekhnolohij, vol. 1(4), pp. 51-54.

5. Karmanova, T.I. (2014), "Cross-Cultural Differences in International Marketing”, Molodoj uchenyj, vol. 10, pp. 245-248.

6. Petrushenko, Yu.M. (2009), "Cross-cultural aspects of increasing the efficiency of international business", Visnyk Khmel'nyts'koho natsional'noho universytetu, vol. 5, pp. 146-148.

7. Pryiatel'chuk, O.A. (2006), "Evolution and theoretical and methodological formation of cross-cultural management", Zovnishnia torhivlia: pravo ta ekonomika, vol. 4, pp. 131-134.

8. Hofstede, Gert. (2011), "And his theory of cultural changes: an overview", [Online], available at: http://news.telelangue.com/ru/2011/10/hofstede-cultural-theory (Accessed 9 December 2019).

9. Shapkina, V.V. (2010), "Features of cross-cultural management in the world and in Ukraine", [Online], available at:http://www.rusnauka.com/14 NPRT_2010/Economics/66680.doc.htm (Accessed 10 December 2019).

10. Gertsen M. (2000). Cultural change processes in mergers: A social constructionist perspective, Copenhagen Business School, Frederiksberg, Denmark.

Література.

1. Годвінг Вонг (2009). Три запоруки успішного крос-культурного менеджменту. URL: http://www.mim.kiev.ua/press/news/2009/1593/ (дата звернення 05.12.2019).

2. Єфімова А.Г. Розвиток крос-культурного менеджменту на підприємствах України. Управління розвитком. 2012. № 6. С. 44-45.

3. ЗУ «Про зовнішньоекономічну діяльність». URL: https://zakon.rada.gov.ua/laws/show/959-12 (дата звернення 09.12.2019).

4. Калиберда Л.П. Кросс-культурный менеджмент и формирование культурной компетенции студентов. Вісник Київського інституту бізнесу та технологій. Київ: КІБІТ. 2006 Вип. 1 (4). С. 51-54.

5. Карманова Т.И. Проблемы кросс-культурных различий в международном маркетинге. Молодой ученый. 2014. № 10. С. 245-248.

6. Петрушенко Ю.М. Крос-культурні аспекти підвищення ефективності міжнародного бізнесу. Вісник Хмельницького національного університету. 2009. № 5. С. 146-148.

7. Приятельчук О.А. Еволюція та теоретико-методологічне становлення кроскультурного менеджменту. Зовнішня торгівля: право та економіка. 2006. № 4. С. 131-134.

8. Хофстеде Герт и его теория измерений культур: обзорная информация. URL: http://news.telelangue.com/ru/2011/10/hofstede-cultural-theory (дата звернення 09.12.209).

9. Шапкіна В.В. Особливості крос-культурного менеджменту у світі та в Україні. URL: http://www.rusnauka.com/14_NPRT_2010/Economics/66680.doc.htm (дата звернення 10.12.2019).

10. Gertsen M. (2000). Cultural change processes in mergers: A social constructionist perspective, Copenhagen Business School, Frederiksberg, Denmark. 